軽金属 第 59 巻 第 9 号 (2009), 509-520

$$
\text { アルミニウム合金用双ロールキャスタ }
$$

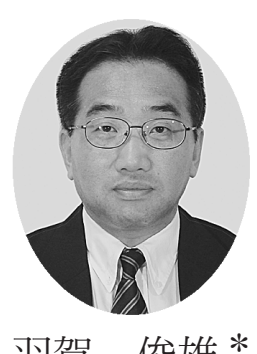

羽賀 俊雄 $*$

Journal of Japan Institute of Light Metals, Vol. 59, No. 9 (2009), pp. 509-520

\title{
Twin roll casters for aluminum alloys
}

Toshio HAGA*

Keywords: twin roll caster, thin strip, strip casting, continuous casting

\section{1.はじめに}

双ロールキャス夕は, 転炉で有名なヘンリー・ベッセマー が発明し，その歴史は 150 年に及ぶ。1 950 年代には，日本で 屯研究が始まった。早稲田大学の松浦佑次名誉教授, 同草川 隆次名誉教授らにより早稲田大学各務記念鋳物研究所（現在 の材料技術研究所）で鋳鉄板や高けい素鋼板などの先駆的な 研究が行われた ${ }^{1)}$ 。しかし，他の鋳造方法や加工方法と比心゙ るとその発展は遅々としていたと言っても過言ではない。そ の理由は, 克服すべき問題点が多かったためである。双ロー ルキャスタは, 打もに鉄鋼とアルミニウムの分野で発展して きたが，両者の双ロールキャス夕は異なっており，個々に発 展してきた。ここでは, アルミニウム用の双ロールキャスタ について解説する。

アルミニウム合金では, 1954 年に Joseph Hunter が下方から 注湯する方式の実用機を開発した ${ }^{2)}$ 。以後今日に至るまで研 究開発が続けられている。近年, 双ロールキャス夕は, 地球 温暖化問題の解決のため, 省工程・省エネルギーおよびリサ イクルアルミニゥム合金の材質の改善から注目されている。 双ロールキャスタは省工程・省エネルギーの視点からは，最 屯優れたプロセスの一つと考えられる。それは双ロールキャ

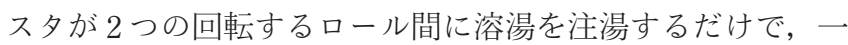
工程で溶湯から薄板を直接鋳造することができるプロセスだ からである。従来の DC (Direct Chill) 鋳造から薄板を作製す るプロセスでは，高価な熱間圧延機を使用した熱間圧延工程 が必要であったが，双ロールキャス夕を使用したプロセスで は, この熱間圧延の工程を省略できる。このため熱間圧延の 設備投資費用の削減やそのランニングコストの削減が期待で きるので，双ロールキャス夕は DC 鋳造・熱間圧延のプロセ スと比較して薄板を安価に作製することができる。双ロール キャス夕は, $700^{\circ} \mathrm{C} / \mathrm{s}$ 程度 ${ }^{3)}$ の高い冷却速度が得られ, 晶出 物が微細分散する。このためリサイクル材では不純物として 鉄が増加しても，曲げ性の劣化の低減が期待できる。また， アルミニウム合金のマトリックスに $\mathrm{SiC}$ の粉末を添加した低 熱膨張材やマグネシウム合金などの冷間圧延が困難な材料の
薄板をロールキャスタで作製することが試みられている。こ のように双ロールキャス夕は, 省工程・省エネルギー, 材質 の改善, 難加工材の薄板の作製が可能であるなどの利点を有 している。しかし，アルミニウム合金用双ロールキャス夕は， ロール周速が $6 \mathrm{~m} / \mathrm{min}$ 以下と遅く, 生産性が低いことが問題 視されている。生産性の改善により, 薄板作製のコストをさ らに低減できると考えられ, ロール周速の高速化はアルミニ ウム合金用の双ロールキャス夕の課題である。

\section{2. 軽合金用双ロールキャスタの変遷}

アルミニウム合金用の双ロールキャスタでは, Hunter と Pechineyが世界をリードしてきた。アルミニウム合金用双 ロールキャスタは, 実用化されているものは第 1 世代, 第 2 世代, 第 3 世代の 3 つの世代に分けることができると思われ る。研究に関しては, 第 3 世代に関することは, ほぼ終了し たと思われる。次世代，つまり第 4 世代の双ロールキャス夕 がどのようなものになるのかは，想像しにくい。

第 1 世代は，アルミニウム合金用双ロールキャスタの創成 期である。1954 年には倒立縦型（図 1（a））の Hunter Standard Caster ${ }^{2), 4)}$ が開発された。縦型であることと下方から 注湯する点に特徴がある。チップ（溶湯をロール間隙に注湯 するためのノズル）先端の溶湯の圧力が低く注湯の開始が容 易であった。しかし，注湯設備と結合したチップの調整およ

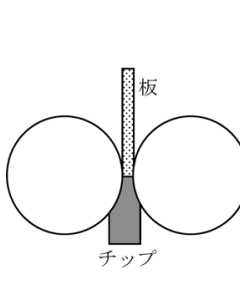

(a)

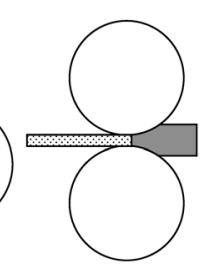

(b)

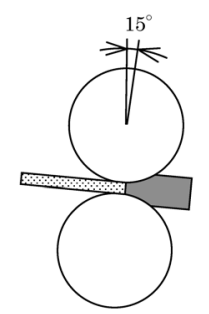

(c)

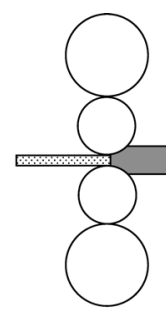

(d)
図 1 アルミニウム合金用各種双ロールキャス夕
(a) Hunter 初期,

(d) 4 段 (Davy)

*大阪工業大学工学部機械工学科（＝ 535-8585 大阪府大阪市旭区大宮 5-16-1）。 Department of Mechanical Engineering, Osaka Institute of Technology (5-16-1 Omiya, Asahi-ku, Osaka-shi, Osaka 535-8585).E-mail: haga@med.oit.ac.jp 受付日：平成 21 年 3 月 31 日 受理日：平成 21 年 6 月 2 日 
び交換に手間がかかる，注湯初期に板のループを形成するの が容易ではないなどの欠点も存在した。1962 年には生産機と しては世界初の横型であり Pechiney 3C（図1（b)）の原型に なる Harvey Caster ${ }^{2)}$ が開発された。1970 年には, Hunter が横 型の板の出口側を上方に 15 度傾けたタイプ（図 1 (c)）を開 発した ${ }^{2,4)}$ 。これにより横型の双ロールキャス夕における注 湯初期の溶湯の漏れ，鋳造板の表面品質が改善された。薄板 の引出し, チップやその周辺設備の交換方法む容易になった。 このロールのハウジングとチップを 15 度傾けた方法は, 以 後 Hunter の特徵となる。ロール径は $500 \sim 700 \mathrm{~mm}$, 単位幅あ たりの荷重は $0.4 \mathrm{t} / \mathrm{mm}$ であった。板幅は $1 \mathrm{~m}$ 以下，板厚は 5 10 mm であり，単位幅・単位時間あたりの生産量は $1.2 \mathrm{t} / \mathrm{m} / \mathrm{h}$ であった。 1 個のモー夕で 2 個のロールを駆動するシ ングルドライブ方式にかわり，1個のロールを 1 個のモー夕 で駆動するデュアルドライブ方式む採用された。2 個のロー ルの速度を別々に制御することで, 薄板のロールへの固着を 防ぐ工夫むされた。

第 2 世代では，ロールの大型化により鋳造できる合金種の 拡大，鋳造板の幅広化が行われた。1975 年にはHunter では SuperCaster, Pechiney では Jumbo3C が開発された2,4)。ロー ル径は 900 1200 mm，板幅は $2 \mathrm{~m}$ まで鋳造可能になった。単 位幅荷重屯第 1 世代の $0.4 \mathrm{t} / \mathrm{mm}$ から第 2 世代では $1.22 \mathrm{t} / \mathrm{mm}$ に増大した。生産量は $1.2 \mathrm{t} / \mathrm{m} / \mathrm{h}$ から $1.8 \mathrm{t} / \mathrm{m} / \mathrm{h}$ に増加した。 1980 年代半ばには $\mathrm{Al}-\mathrm{Mg}$ 系の合金板も鋳造できるようになっ た。板厚は，5１0 mm であり，これより薄い板の鋳造は困難 であった。第 1 世代と第 2 世代の双ロールキャス夕で鋳造し た板の典型的な欠陥は，板の内部では中心線偏析，板の表面 ではリップルマークであった。これらの欠陥については後で 示す。第 2 世代の Super Caster では, 板を $5.7 \mathrm{~mm}$ より薄くす るとロール周速を速くすることができるので若干ではあるが
生産性が向上し, リップルマークあ改善されることが明らか になった ${ }^{5)}$ 。これは第 3 世代の双ロールキャスタで取入れら れた板の薄化による高速化のヒントになったと思われる。

第 3 世代の特徵は, 生産性の向上を目的とした鋳造板の薄 化によるロール周速（鋳造速度）の高速化，つまりThingage/High-speed である。板厚が $5 \mathrm{~mm}$ より薄くなると生産量 が向上し始め， $3 \mathrm{~mm}$ より薄くなるとそれが顕著になるとさ れている。1990 年半ばに Hunter では Speed Caster ${ }^{2), 4) ~ 13) ~ か ゙ ~}$ 開発された。厚さ $2 \mathrm{~mm}$ 以下の板の鋳造が可能になりロール 周速む $10 \mathrm{~m} / \mathrm{min}$ 以上が可能になった。単位幅荷重は 1.4 $\mathrm{t} / \mathrm{mm}$, 生産量は $3.9 \mathrm{t} / \mathrm{m} / \mathrm{h}$ まで向上した。同じく 1990 年代 半ばには Hunterの Super Caster Plus ${ }^{2), 4), 7), 8) や ~ P e c h i n e y ~ の ~}$

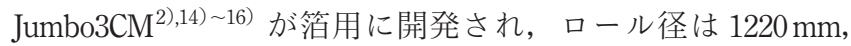
双ロールキャス夕の耐荷重は $3,400 \mathrm{t}$ ，単位幅荷重は $2.0 \mathrm{t} / \mathrm{mm}$ に達した。鋳造板の薄化により, 後工程の 3 回の冷間圧延を 2 回に減らすことが可能になった ${ }^{9)}$ 。

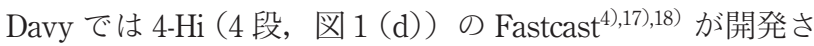
れた。ワークロール（鋳造ロール）のベンディングによって 板厚分布を制御することが可能であった。バックアップロー ルを駆動する方式を採用したため, 鋳造ロールの水冷が容易 であった。また，鋳造ロールは他のキャス夕より小径であり シェルの厚さが薄くてもトルクに耐えられるとされている。 バックアップロールと鋳造ロールが摩擦するため, 鋳造ロー ルのロールコーティングが剥離し，板の表面状態を害すると いったこの方法に特有な欠点もあるとされている。

Hunter の SpeedCaster と Pechiney の Jumbo3CM のライン構 成を図 $2^{5), 14)}$ に示す。どちらむキャス夕以後の後工程に相違 は見られない。第 1, 2 世代のロールキャス夕や Fastcast では

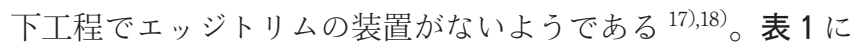
各世代のキャス夕の比較を示す。

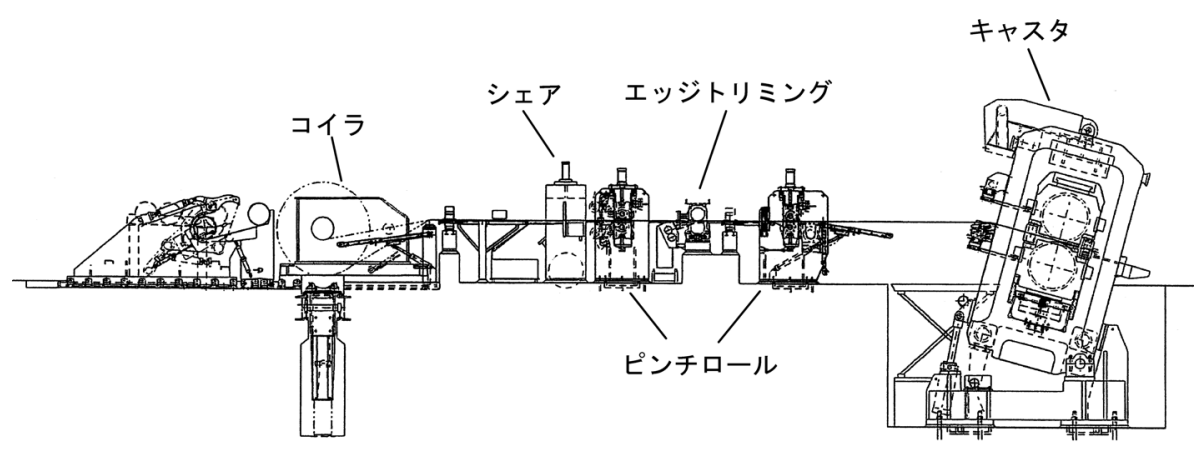

(a) Hunter Speed Caster のライン構成

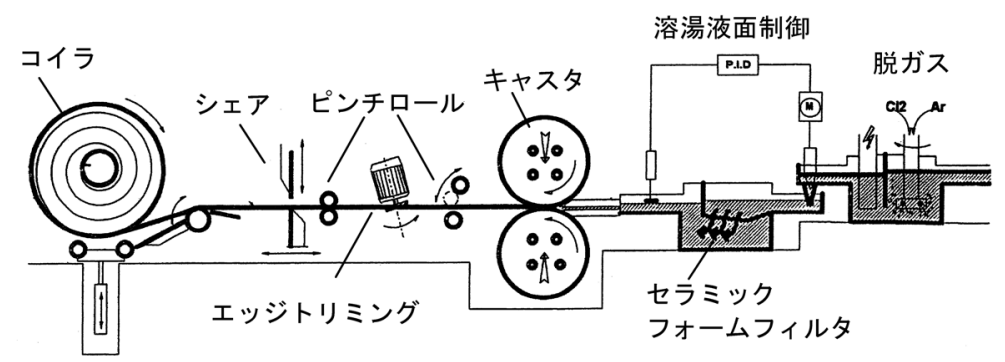

(b ) Pechiney Jumbo 3CM のライン構成

図 2 双ロールキャスタのライン構成例 5),14) 
表 1 アルミニゥム合金用キャス夕の变遷と比較

\begin{tabular}{c|c|c|c|c|c|c}
\hline \hline & 年 代 & 板幅 $(\mathrm{m})$ & 板厚 $(\mathrm{mm})$ & ロール径 $(\mathrm{mm})$ & 荷重 $(\mathrm{t} / \mathrm{mm})$ & 生産性 $(\mathrm{t} / \mathrm{m} / \mathrm{h})$ \\
\hline 第一世代 & 1950 年 & $\sim 1$ & $5 \sim 10$ & $500 \sim 700$ & 0.4 & 1.2 \\
\hline 第二世代 & 1975 年 & $\sim 2$ & $5 \sim 10$ & $900 \sim 1200$ & 1.22 & 1.8 \\
\hline 第三世代 & 1992 年 & $\sim 2.2$ & 2 以下 & $\sim 1220$ & 2.0 & 3.9 \\
\hline
\end{tabular}

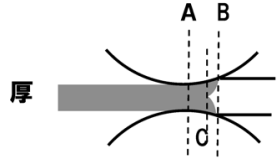

低 速

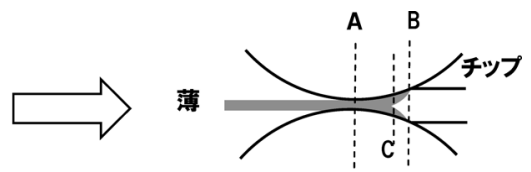

高 速
図 3 ロール周速，チップの位置，板厚とロール間隙の 凝固層の関係

\section{3. 板の薄化と生産性の向上}

双ロールキャス夕の重要な改善点の一つに生産性の向上が ある。1990 年代に入り，生産性の向上が精力的に検討される ようになった。板厚を薄くしロール周速を高める方法である。 ロール周速，チップ先端の位置，板厚とロール間隙の溶湯の 凝固層の関係の模式図を図 3 に示す。高速になるに従い凝固 時間が短くなるので板は薄くなり，板の温度む上昇する。高 速になるに従いチップ先端から上下の凝固層が接触するまで の距離 $\mathrm{BC}$ は長くなり，逆に圧下する距離 $\mathrm{AC}$ は短くなる。 $\mathrm{AC}$ における薄板とロール間の熱伝達量は， $\mathrm{BC}$ の凝固した層 とロール間の熱伝達量より大きい。ロール周速が過度に速く なると薄板が十分に冷却されず，連続的な薄板の作製が困難 な場合もある。これを解決するためにロール間隙に溶湯を供 給するチップ先端からロール間隔が最も狭くなる位置までの 距離 $\mathrm{AB}$ (セットバック長) を長くし，ロール間隙を狭くす る。これは，ロールが薄板を圧下する距離 $\mathrm{AC}$ を，ロール周 速の高速化に伴い長くすることが目的である。AC間では薄 板は圧下されるため，板とロール間の接触状態は良好であり， 冷却ゾーンが長くなる。 $\mathrm{AC}$ を長くするためには圧下量を大 きくすることが必要である。圧下量の増大に伴い板は薄くな るので冷却は容易になる。 $\mathrm{AC}$ を長くすることおよび圧下量 を増して板を薄くすることで，高ロール周速でも板を十分に 冷却することができる。また，ロール周速の高速化に伴い圧 下量を大きくすることは，中心線偏析の改善にも有効である。

Hunter の SpeedCaster の板厚と生産量の関係を図 4 ${ }^{8)}$ に示 す。板厚が薄くなるに従い鋳造速度が増すため生産量む増す。 板厚が $3 \mathrm{~mm}$ 以下になると生産量の増加が著しい。1100 板の 鋳造を例に取って SuperCaster と SpeedCaster のロール周速, 板厚，生産量の比較を表 $2^{8)}$ に示す。SpeedCaster は SuperCaster に対して鋳造速度は約 8 倍，板厚は約 4 分の 1 に なり生産量は約 2 倍になっている。これは単純に考えれば, 2 台の SuperCaster を 1 台の SpeedCaster で置き換えることが できることを意味する。年間 $20,000 t$ の箔を生産する場合の SpeedCaster と SuperCaster の設備費の比較を表 $3^{9 ）}$ に示す。 SpeedCaster を使用した場合は SuperCaster より生産性が高い ため，双ロールキャス夕を 1 台にすることができる。

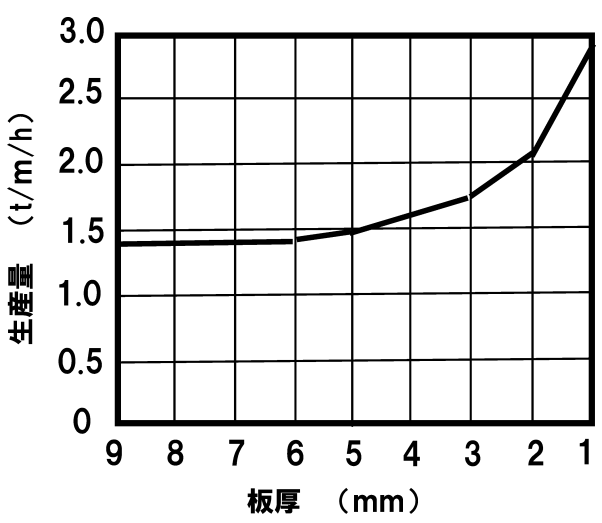

図 4 板厚と生産量の関係 ${ }^{8)}$

表 2 Super Caster と Speed Caster の比較（1100 を鋳 造する場合) ${ }^{8)}$

\begin{tabular}{l|c|c}
\hline \hline \multicolumn{1}{c|}{ 比較項目 } & Speed Caster & Super Caster \\
\hline 鋳造速度 $(\mathrm{m} / \mathrm{min})$ & 14 & 1.7 \\
板厚 $(\mathrm{mm})$ & 1.3 & 5.6 \\
生産量 $(\mathrm{t} / \mathrm{m}$, width/h) & 2.9 & 1.5 \\
引張強さ $(\mathrm{MPa})$ & 118 & 118 \\
耐力 $(\mathrm{MPa})$ & 90 & 83 \\
\hline
\end{tabular}

SpeedCaster の鋳造板は薄くなるため, 薄板を中間箔圧延機で 圧延することができるので冷間圧延機を必要としなくなる。 設備費は SpeedCaster を使用すると SuperCaster の約 73\% に減 らすことができる。

SuperCaster と SpeedCaster では, 図 55)に示すように鋳造 板の組織の違いも著しい。SuperCaster で鋳造した $5.6 \mathrm{~mm}$ の 板では中心線偏析が顕著であるが, SpeedCaster で鋳造した $1.3 \mathrm{~mm}$ の板では板厚中央部屯高圧下による組織の変形が著し く, 偏析が改善されている。SpeedCaster の鋳造板の板厚方向 の中央部之その両側では組織が異なっている。サンプ形状が 図 3 に示すように深くなっているため半凝固状態の時間が長 くなり，圧下前は板厚の中央部では粒状に近い組織になって いると推測される。しかし, SuperCaster と SpeedCaster では 冷間圧延と焼なまし後の組織には差異はなく, 機械的性質む ほぼ等しかったと報告されている。

SpeedCaster により 1.8，3，5 $\mathrm{mm}$ の厚さの 1050 板を鋳造 し，組織や機械的性質に対する板厚の影響が調查された。表 $4^{10 ）}$ と表 $5^{10)}$ に 1050 の as-cast 板と冷間圧延・焼なまし後の 薄板の機械的性質を示す。as-cast 板では薄い方が耐力や引張 強さの值が大きく伸びが小さい。これは圧下量が大きいため, 加工硬化量む大きいことが原因と考えられる。板が薄い方が 
表 3 SuperCaster と SpeedCaster の設備費の比較 (年間 20,000 トン生産する場合) ${ }^{9)}$

\begin{tabular}{|c|c|c|c|}
\hline \multicolumn{2}{|l|}{ SpeedCaster } & \multicolumn{2}{|l|}{ SuperCaster } \\
\hline 設備 & 数 & 設備 & 数 \\
\hline $50 \mathrm{t}$ 溶解炉 & 1 & $32 \mathrm{t}$ 溶解炉 & 2 \\
\hline $25 \mathrm{t}$ 保持炉 & 1 & 16t 保持炉 & 2 \\
\hline 脱ガス，フィルタ & 1 & 脱ガス，フィルタ & 2 \\
\hline 1650 mm 幅 SpeedCaster & 1 & 1650 mm 幅 SuperCaster & 2 \\
\hline 冷間圧延機 & 0 & $400 \cdot 965 \mathrm{~mm} \quad 2500 \mathrm{Hp}$ 冷間圧延機 & 1 \\
\hline 60 t コイル焼なまし炉 & 4 & 60 tコイル焼なまし炉 & 4 \\
\hline $300 \cdot 900 \mathrm{~mm}, 1500 \mathrm{~m} / \mathrm{min}$ 中間箔圧延機 & 1 & $280 \cdot 850 \mathrm{~mm}, 1500 \mathrm{~m} / \mathrm{min}$ 中間箔圧延機 & 1 \\
\hline $280 \cdot 900 \mathrm{~mm}, 1500 \mathrm{~m} / \mathrm{min}$ 仕上箔圧延機 & 1 & $280 \cdot 850 \mathrm{~mm}, 1500 \mathrm{~m} / \mathrm{min}$ 仕上箔圧延機 & 1 \\
\hline フォイルセパレータ & 2 & フォイルセパレータ & 2 \\
\hline フォイルスリッタ & 1 & フォイルスリッタ & 1 \\
\hline 20 t箔焼なまし炉 & 6 & 20 t箔焼なまし炉 & 6 \\
\hline 装置価格 & ドル & 装置価格格 & 0 ドル \\
\hline
\end{tabular}

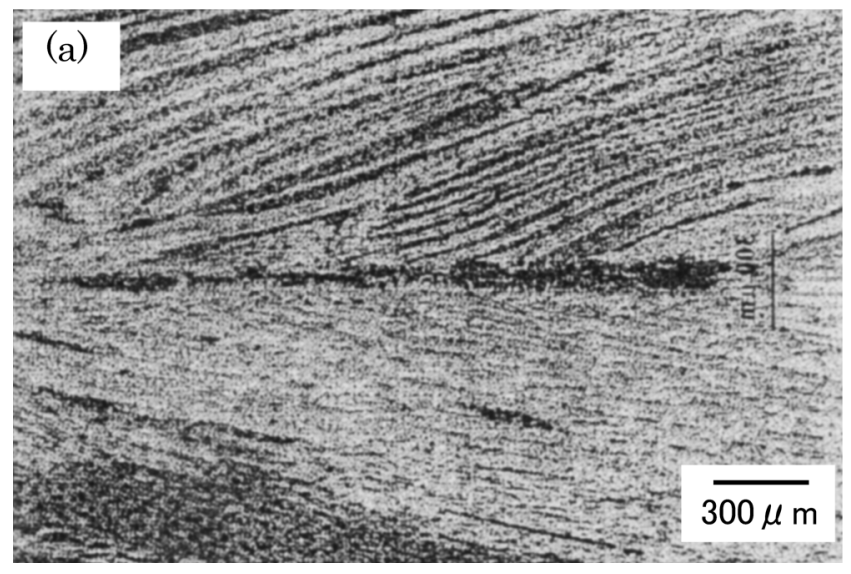

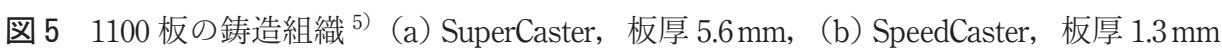

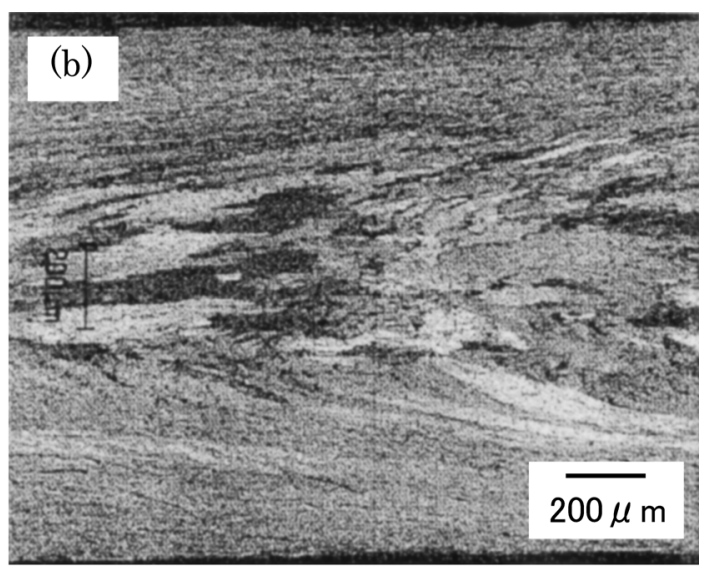

表 5 冷間压延・焼なまし後の 1050 板の機械的性質 に対する as-cast 板の厚さの影響 10)

\begin{tabular}{c|c|c|c|c|c}
\hline \hline $\begin{array}{c}\text { 板厚 } \\
(\mathrm{mm})\end{array}$ & $\begin{array}{c}\text { 測定 } \\
\text { 方向 }\end{array}$ & $\begin{array}{c}\text { 耐力 } \\
(\mathrm{MPa})\end{array}$ & $\begin{array}{c}\text { 引張強さ } \\
(\mathrm{MPa})\end{array}$ & $\begin{array}{c}\text { 伸び } \\
(\%)\end{array}$ & $\mathrm{r}$ 值 \\
\hline \multirow{3}{*}{5} & $0^{\circ}$ & 77 & 94 & 37 & 0.50 \\
& $45^{\circ}$ & 76 & 89 & 36 & 0.90 \\
& $90^{\circ}$ & 77 & 92 & 35 & 0.55 \\
\hline \multirow{3}{*}{3} & $0^{\circ}$ & 83 & 101 & 33 & 0.41 \\
& $45^{\circ}$ & 78 & 93 & 31 & 1.35 \\
& $90^{\circ}$ & 81 & 102 & 35 & 0.55 \\
\hline \multirow{3}{*}{1.8} & $0^{\circ}$ & 93 & 106 & 25 & 0.42 \\
& $45^{\circ}$ & 91 & 100 & 24 & 1.14 \\
& $90^{\circ}$ & 94 & 108 & 21 & 0.54 \\
\hline
\end{tabular}

\begin{tabular}{c|c|c|c|c|c}
\hline $\begin{array}{c}\text { 板厚 } \\
(\mathrm{mm})\end{array}$ & $\begin{array}{c}\text { 測定 } \\
\text { 方向 }\end{array}$ & $\begin{array}{c}\text { 耐力 } \\
(\mathrm{MPa})\end{array}$ & $\begin{array}{c}\text { 引張強さ } \\
(\mathrm{MPa})\end{array}$ & $\begin{array}{c}\text { 伸び } \\
(\%)\end{array}$ & $\mathrm{r}$ 值 \\
\hline \multirow{3}{*}{5} & $0^{\circ}$ & 36 & 75 & 38 & 0.73 \\
& $45^{\circ}$ & 36 & 77 & 39 & 0.36 \\
& $90^{\circ}$ & 34 & 74 & 40 & 0.73 \\
\hline \multirow{3}{*}{1.8} & $0^{\circ}$ & 38 & 72 & 37 & 0.74 \\
& $45^{\circ}$ & 36 & 77 & 39 & 0.41 \\
& $90^{\circ}$ & 34 & 72 & 34 & 0.70 \\
\hline
\end{tabular}


結晶や析出物は微細であるが冷間圧延・焼なまし後の薄板の 機械的性質には差異はなかったと報告されている。

\section{4. 鋳造ロール}

ロール径の影響に関しては, 直径が $660 \mathrm{~mm}$ と $1100 \mathrm{~mm}$ の ロールを用いて 3003 合金の厚さ $6 \mathrm{~mm}$ の薄板を鋳造して機械 的性質を比較した例がある。組織には差異は見られなかった。 厚さ $56 \mu \mathrm{m}$ まで冷間圧延して機械的性質が調査されている が，表 6 ${ }^{19 ）}$ に示すように差異は小さかった。圧下時の薄板内 部の半凝固領域の変形と流動を考えるとロール径は大きい方 がよいという考えあある。生産性に対しては，ロール径は影 響を与えないという報告がある。ロール径が小さい方が高圧 下に抢ける特有の欠陥であるバックリングが発生しにくい。 図 6 ${ }^{17)}$ に示すようにロール径が小さい方が，同じ圧下率に対 して荷重が小さくなるので，高圧下に対してはロール径が小 さいほうが有利と考えることもできる。

ロール材質に関する検討屯行われている。鋼に代わり銅合 金を用いた例が報告されている ${ }^{20)}$ 。銅合金のロールの成分を 表 $7^{20)}$ に示す。鋼ロールと銅合金ロールの生産性の比較を表

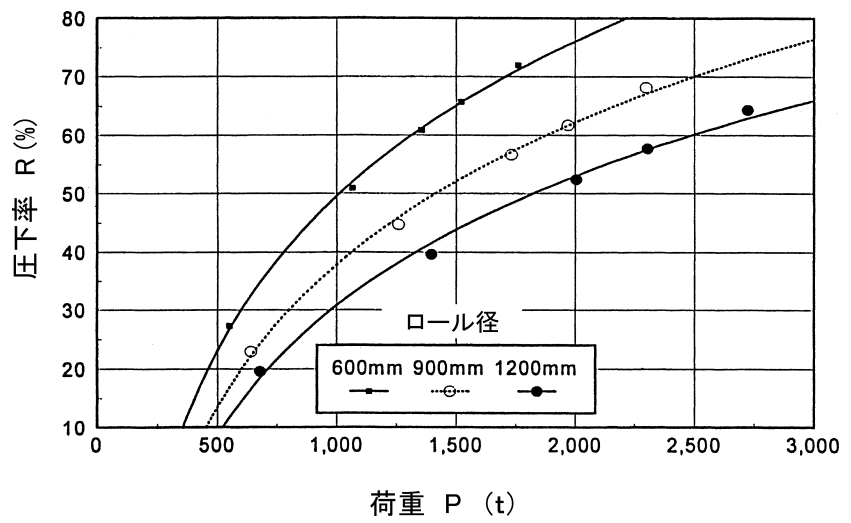

図 6 荷重に対するロール径の影響 17$)$

表 6 厚さ $6 \mathrm{~mm}$ の as-cast 板を $56 \mu \mathrm{m}$ まで冷間圧延した ときの機械的性質に対する鋳造ロール径の影響 ${ }^{19)}$

\begin{tabular}{c|c|c|c|c}
\hline \hline $\begin{array}{c}\text { ロール } \\
\text { 直径 }\end{array}$ & 方向 & $\begin{array}{c}\text { 引張強さ } \\
(\mathrm{MPa})\end{array}$ & $\begin{array}{c}\text { 耐力 } \\
(\mathrm{MPa})\end{array}$ & $\begin{array}{c}\text { 伸び } \\
(\mathrm{MPa})\end{array}$ \\
\hline \multirow{2}{*}{$1100 \mathrm{~mm}$} & $0^{\circ}$ & 141 & 135 & 22 \\
& $90^{\circ}$ & 143 & 136 & 20 \\
\hline $660 \mathrm{~mm}$ & $0^{\circ}$ & 148 & 130 & 21 \\
& $90^{\circ}$ & 144 & 136 & 20 \\
\hline
\end{tabular}

$8^{20)}$ に示す。鋼より熱伝導率が高い銅合金のロールを用いる と生産量は約 2 倍になっている。これはロールの冷却能が向 上したためにロール周速を高速化できたことが原因と考えら れる。生産量に対する各種ロールで鋳造した板の温度を図 $7^{20)}$ に示す。鋳造板の温度は, 鋼ロールを用いた場合は $300^{\circ} \mathrm{C}$ 以上であるが，銅合金ロールを用いた場合は $300^{\circ} \mathrm{C}$ 未満に冷 却される。鋳造板の温度が鋳造速度の上限を決定すると仮定 し, 図 7 の銅合金ロールの鋳造板のグラフを延長して鋼ロー ルの鋳造板の温度と同じになるときの生産量を単純に銅合金 ロールの限界生産速度と判断すると, 銅合金ロールは鋼ロー ルの 3 倍以上の限界生産速度を有すると考えられる。図 ${ }^{20)}$ は銅合金 B の生産量とトルクの関係を示している。生産量が 増すほど，つまりロール周速が増すほど凝固厚さが減少し， また圧下時の板の温度は高くなり变形抵抗が低下するため卜 ルクは減少している。表 920) は，ロールのシェル（厚さ $50 \mathrm{~mm}$ の外皮）が $1 \mathrm{~mm}$ 摩耗するまでの生産量を示す。銅合

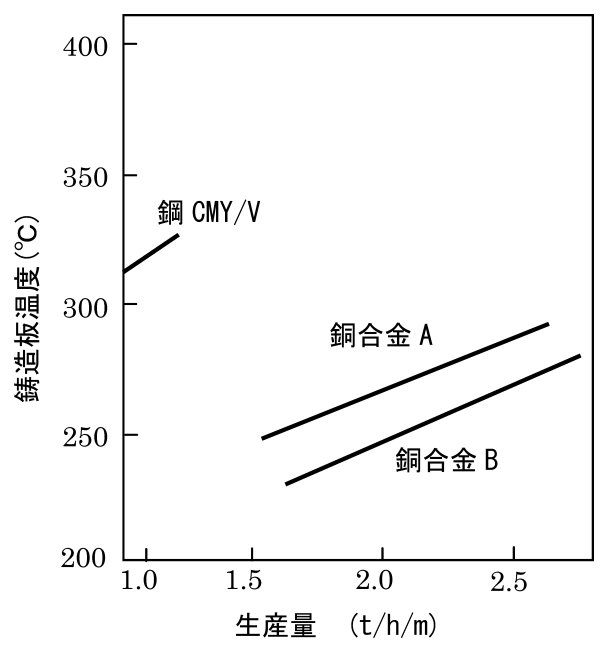

図 7 鋳造板の温度と生産量に対するロール材質の影響 20)

表 8 生産性に対するロール材質の影響（合金 A, B，C は表 7 に対応) 20$)$

\begin{tabular}{l|c|c|c}
\hline \hline \multirow{2}{*}{$\begin{array}{l}\text { ロールに使用 } \\
\text { した合金 }\end{array}$} & \multicolumn{3}{|c}{ 生産量 $(\mathrm{t} / \mathrm{h} / \mathrm{m})$} \\
\cline { 2 - 4 } & 1200 & 8011 合金 & 8079 合金 \\
\hline 銅合金 $\mathrm{A}$ & 2.64 & & \\
銅合金 $\mathrm{B}$ & 2.68 & 2.45 & 2.68 \\
銅合金 C & 3.17 & & \\
鋼 $\mathrm{CMY} / \mathrm{V}$ & 1.36 & 1.15 & 1.18 \\
鋼 MO22 & 1.28 & 1.06 & 1.12 \\
\hline
\end{tabular}

表 7 銅ロールの成分 ${ }^{20)}$

\begin{tabular}{c|c|c|c|c|c|c|c|c|c}
\hline \hline 合金 & $\mathrm{Be}$ & $\mathrm{Co}$ & $\mathrm{Cr}$ & $\mathrm{Mg}$ & $\mathrm{Ni}$ & $\mathrm{Si}$ & $\mathrm{Zr}$ & others & $\mathrm{Cu}$ \\
\hline $\mathrm{A}$ & 0.4 & 2.4 & & & & & & $<0.8$ & $\mathrm{Bal}$. \\
\hline $\mathrm{B}$ & 0.7 & 2.7 & & & & & & & \\
\hline $\mathrm{C}$ & & & 0.43 & & & & 0.31 & & $\mathrm{Bal}$. \\
\hline
\end{tabular}




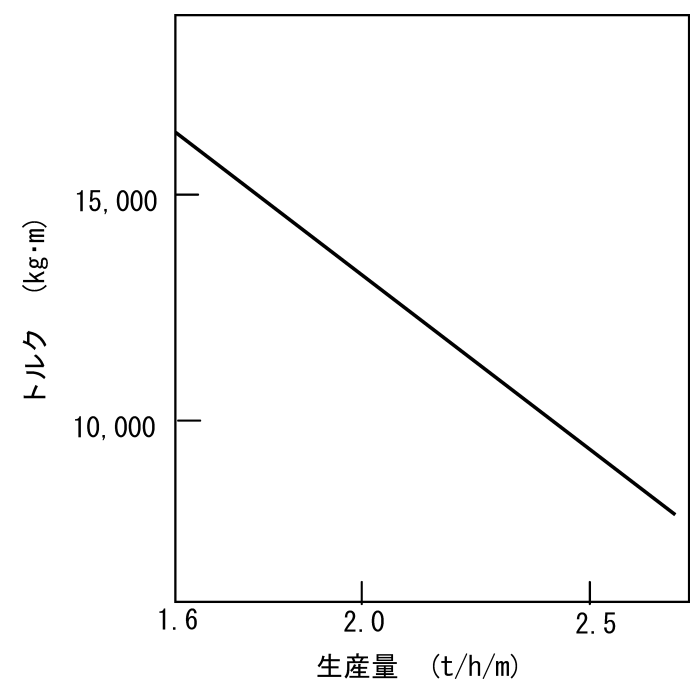

図 8 生産量とトルクの関係（合金 B) ${ }^{20)}$

表 9 ロールが $1 \mathrm{~mm}$ 摩耗するまでの生産量 ${ }^{20)}$

\begin{tabular}{c|c}
\hline \hline ロール材質 & 生産量 $(\mathrm{t})$ \\
\hline 銅合金 $\mathrm{A}$ & 58 \\
銅合 $\mathrm{B}$ & 60 \\
鋼 $\mathrm{CMY} / \mathrm{V}$ & 120 \\
鋼 $\mathrm{MO} 22$ & 200 \\
\hline
\end{tabular}

金ロールは鋼ロールの $30 \%$ から 50\% 程度しか生産できなかっ たとされている。銅合金のロールは熱疲労によりロール寿命 は短くなり，銅合金のロールの使用は経済的な利点はないと されている。しかし，銅合金ロールを用いた場合は鋳造板の 温度は鋼ロールより低いため鋳造板の変形抵抗は増し，銅合 金のロールは㛜しい条件で疲労寿命の試験を行ったことにな る。鋳造板の温度を同一にして鋼ロールと銅合金ロールの寿 命を比較すれば，その差は表 $9^{20)}$ より小さくなると思われる。 いずれにせよ，熱伝導率が高い材質をロールに使用すること は，鋳造速度の高速化には有利であると考えられる。

ロールの水冷は, 図 9 (a) ${ }^{21)}$ に示す方法が一般的である。 図 9 (a) では流水路はコアに加工してあるが，シェルに加工 した例 ${ }^{22)}$ あある。シェルに流水路を加工した方が，冷却効 率はよいとされている。また， ロール面の温度分布を均一に するため，5分ごとに冷却水が流れる方向を変えるなどの工 夫がされている。図 9 (b) ${ }^{21)}$ はロール軸方向に冷却水が流れ るが，流れる方向が交互に逆方向になっているため図 9 (a) の方法よりロール面の温度分布は均一になるとされている。

鋳造中のロールのサーマルクラウンを冷却により制御して いる例屯ある ${ }^{4), 7)}$ 。Davy の Fastcastでは，圧延機のように ロールベンディングで図 1017) に示すように板厚分布を制御 することができる。

\section{5. チップ}

双ロールキャス夕では，ロール間隙に溶湯を供給する部分 はチップ 11),23),24) と呼ばれている。チップとその周辺の模式 図を図 1111),24) に示す。チップの材質は 1980 年代にアスベス トから $\mathrm{SiO}_{2}$ と $\mathrm{Al}_{2} \mathrm{O}_{3}$ を主成分とするセラミックスファイバに

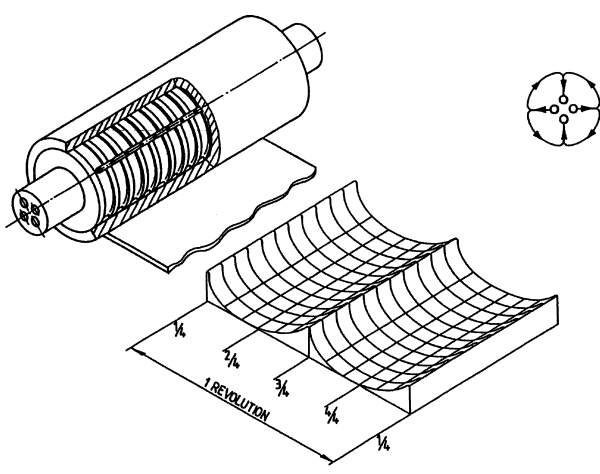

(a)

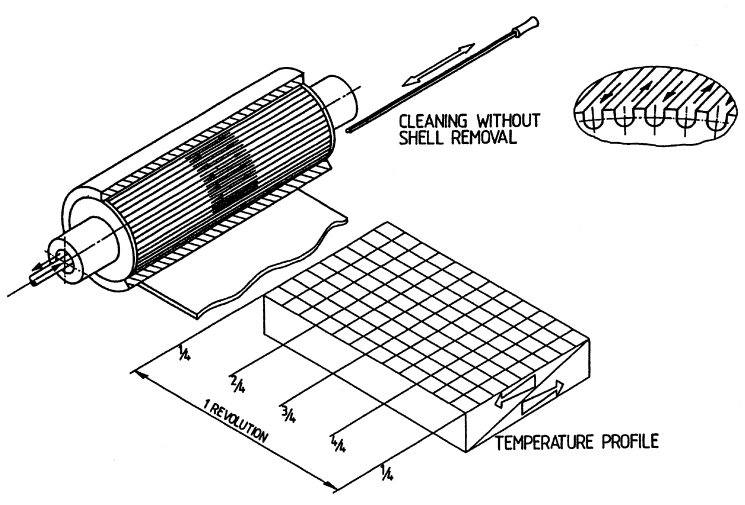

(b)

図 9 ロールの水冷方法 ${ }^{21)}$

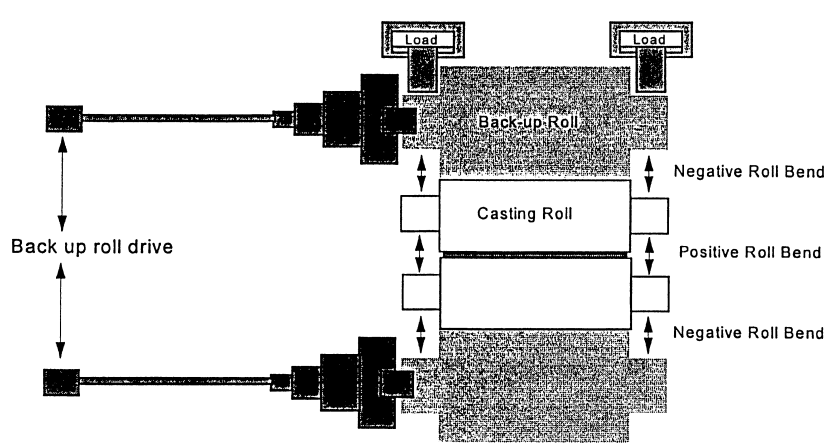

（a） 4 段ロールキャス夕（Davy Fastcast）のロールベンディングの方法

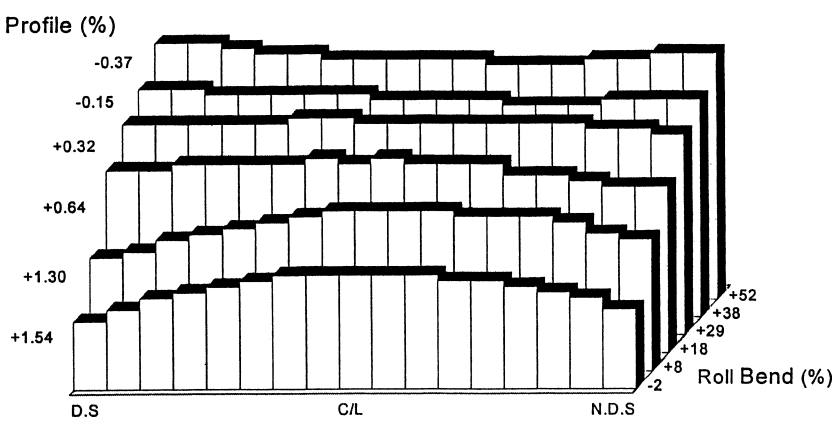

（b）板厚分布に対するロールベンディングの影響

図 10 Davy Fastcast のロールベンディングと板厚分布 ${ }^{17)}$

替わった。チップが操業中に変形せず，また表面に割れや剥 離が起こらないためにはチップの材質に剛性, 断熱性, 耐熱 性が必要とされ，これらについて調査した例がある ${ }^{13), 23) 。 ~}$ ロール幅方向で溶湯の流速や温度が一定であることや連続使 


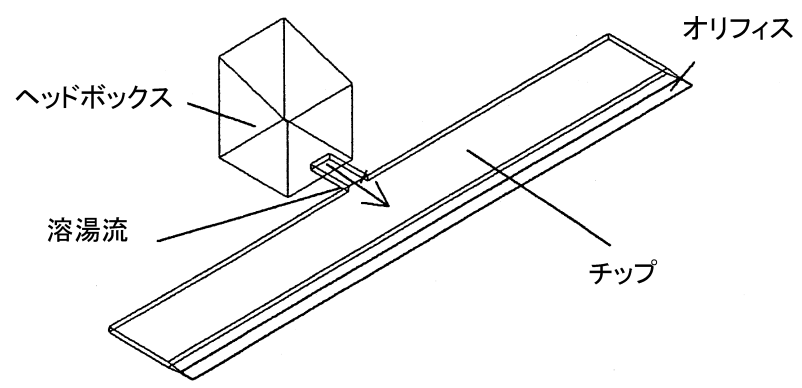

（a）チップとヘッドボックスの模式図

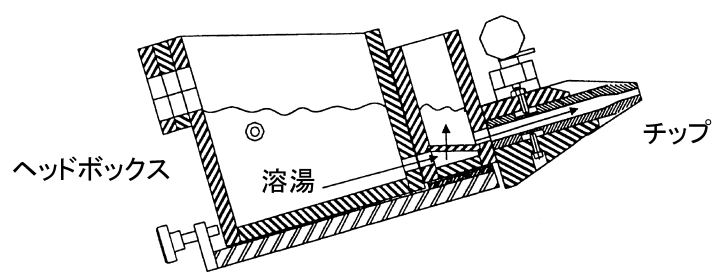

（b）溶湯の清浄効果を考慮した溶湯の供給

図 11 チップとヘッドボックスの模式図 ${ }^{11), 24}$

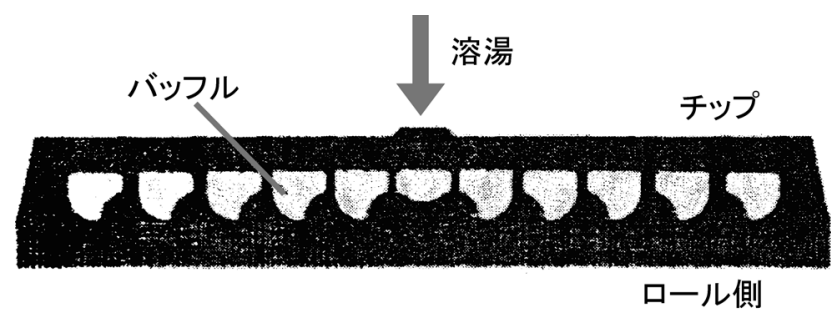

（a）バッフルの形状の解析例

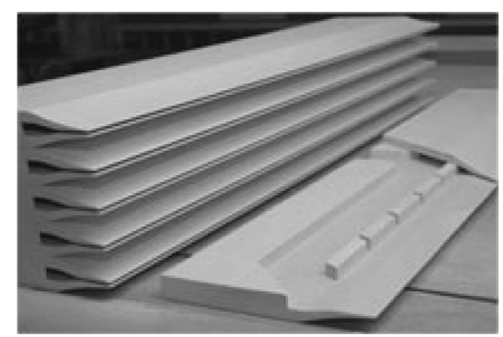

(b) 実機のチップとバッフル

図 12 チップ内のバッフル 24),25)

用に耐えられることが，チップには要求される。チップ内の 溶湯の流れについては，図 12 ${ }^{24), 25)}$ に示すバッフル（baffle） と呼ばれるコマによる整流効果について解析もされている。 チップの両サイドのダムの位置を制御することで板幅を鋳造 中に変えることも行われている26)。

液面の測定はレーザ変位計で $\pm 0.4 \mathrm{~mm}$ 以内の精度で測定さ れ, ヘッドボックス内の液面位置は $\pm 1 \sim 2 \mathrm{~mm}$ で制御されて (る ${ }^{11), 13), 18)}$ 。システムの例を図 13 ${ }^{18)}$ に示す。液面位置や チップとロールの間隙は, 図 14 ${ }^{11)}$ に示すようにチップ先端 の溶湯のメニスカスの形状に影響し，鋳造板の表面の偏析の 原因になると考えられている。

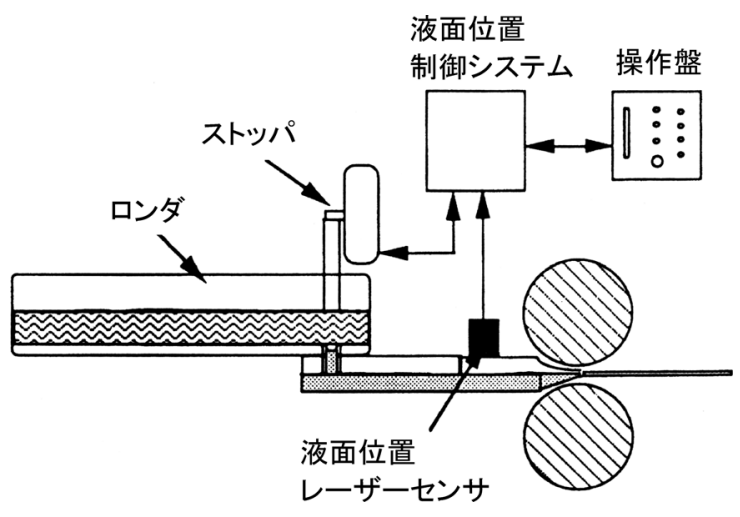

図 13 液面位置の測定と制御システムの模式図 ${ }^{13)}$
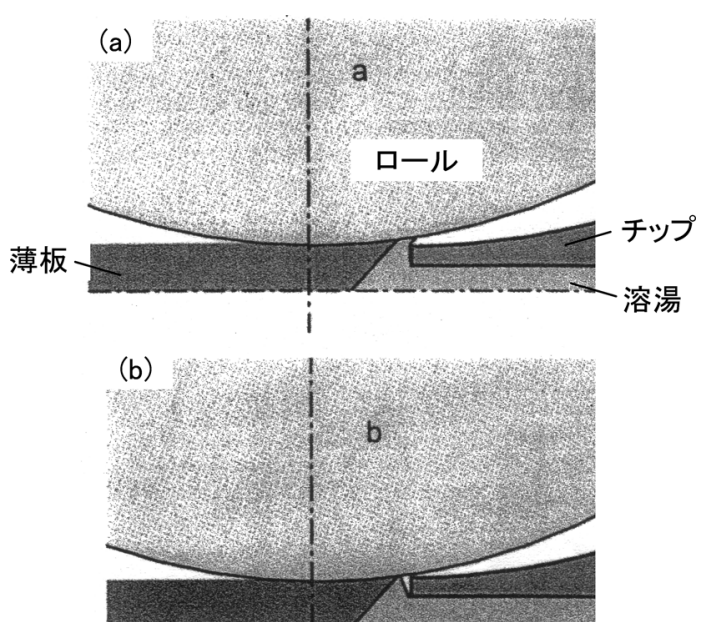

図 14 溶湯のメニスカスに対するロールとチップの間隙 の影響 11）（a）間隙が広すぎてメニスカスは不 安定，（b）間隙は狭くメニスカスの形状は適切

\section{6. 内部欠陥}

板厚が同じ場合はロール周速が速いほど偏析は著しい。偏 析がない板を鋳造するためには，ロール周速が速くなるほど 板厚を薄くする必要がある ${ }^{12)}$ 。双ロールキャスタで鋳造した 板の内部の偏析は, 荷重の影響を強く受け荷重が高くなるに 従いバンド組織, 変形偏析, チャンネル偏析, 分散偏析, 偏

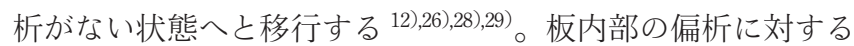
荷重と板厚の影響を図 15 ${ }^{28)}$ に示す。ロールキャスト板の内 部欠陥としては中心線偏析が知られているが，通常中心線偏 析はチャンネル偏析を指す。チャンネル偏析の状態を図 16 30),31) に示す。図 16 にはチャンネル偏析に対するロール周 速とセットバック長の影響屯示されている。ロール周速は遅 くセットバック長が短い場合, つまり圧下量が大きくなる条 件においてチャンネル偏析は軽減されるようである。

\section{7. 表面欠陥}

リップルマークはレベルラインとも呼ばれ双ロールキャス タで鋳造した板の表面欠陷として知られている ${ }^{13), 27), 32) 。 リ ッ ~}$ プルマークの例を図 17 ${ }^{32)}$ に示す。チップ先端のメニスカス が変動し, 凝固層と干渉することでリップルマークが発生す

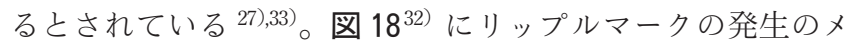
カニズムを示す。ロール周速, チップとロールの間隙, ロー 
ル面に対するチップの角度などメニスカスの形状に影響を与 える条件を適切に制御することでリップルマークの発生を防 ぐことができるようである。

表面の偏析はブリード 28),29) と呼ばれている。ブリードは, 図 1928),29) に示すようにロールと半凝固状態の材料の間にで

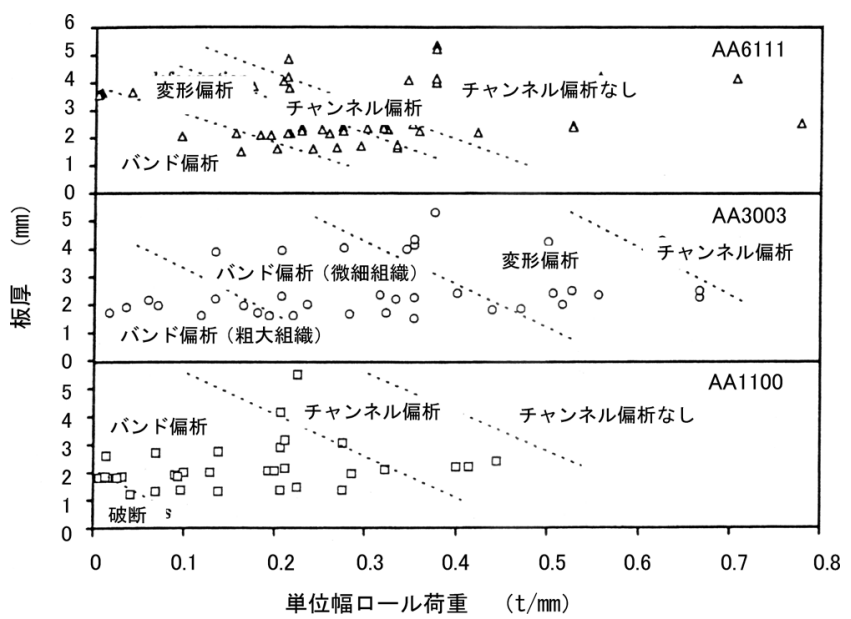

図 15 偏析に対する荷重と板厚の影響 28)
きた隙間に液相が染み出すことにより形成される。小さいも のでは長さ $0.05 \mathrm{~mm}$ で深さが $0.01 \mathrm{~mm}$ ，大きいものでは長さ $1.5 \mathrm{~mm}$ で深さ $0.1 \mathrm{~mm}$ 程度とされている。荷重の大小により 2 種類に分けられている。荷重が小さい場合はブリードの中に 初晶が晶出するが，荷重が大きい場合は共晶組織になる傾向 がある。ブリードの発生とロール荷重の関係を図 2033)に示 す。ロール荷重が大きいほど, つまり圧下量が多いほどブ リードは発生しにくいようである。

\section{8. 難加工材への利用}

Duralcan に代表されるアルミニウム合金マトリックスに $\mathrm{SiC}$ の粉末を添加した複合材料は, 而摩耗性や低熱膨張性に優れ ている。しかし, この複合材は硬く脆いため, 塑性加工によ り薄板を作製するには非常に多くの熱間圧延の工程を必要と した。双ロールキャスタにより平均粒径 $10 \mu \mathrm{m}$ の $\mathrm{SiC}_{\mathrm{p}}$ を $20 \mathrm{vol} \%$ まで添加した薄板の作製が試みられている ${ }^{34), 35)}$ 。 $\mathrm{SiC}_{\mathrm{p}}$ の添加は鋳造が困難になるほど双ロールキャスト性に影響を 与えないようである。また, 表面欠陥も発生しなかったと報 告されている。マトリックスには $\mathrm{Al}-\mathrm{Si}-\mathrm{Mg}$ 系の鋳造用合金 が使用されているため，板の鋳造が可能であったと思われる。 $\mathrm{SiC}_{\mathrm{p}}$ は $10 \mathrm{vol} \%$ より $20 \mathrm{vol} \%$ の方が板厚方向で均一に分布し
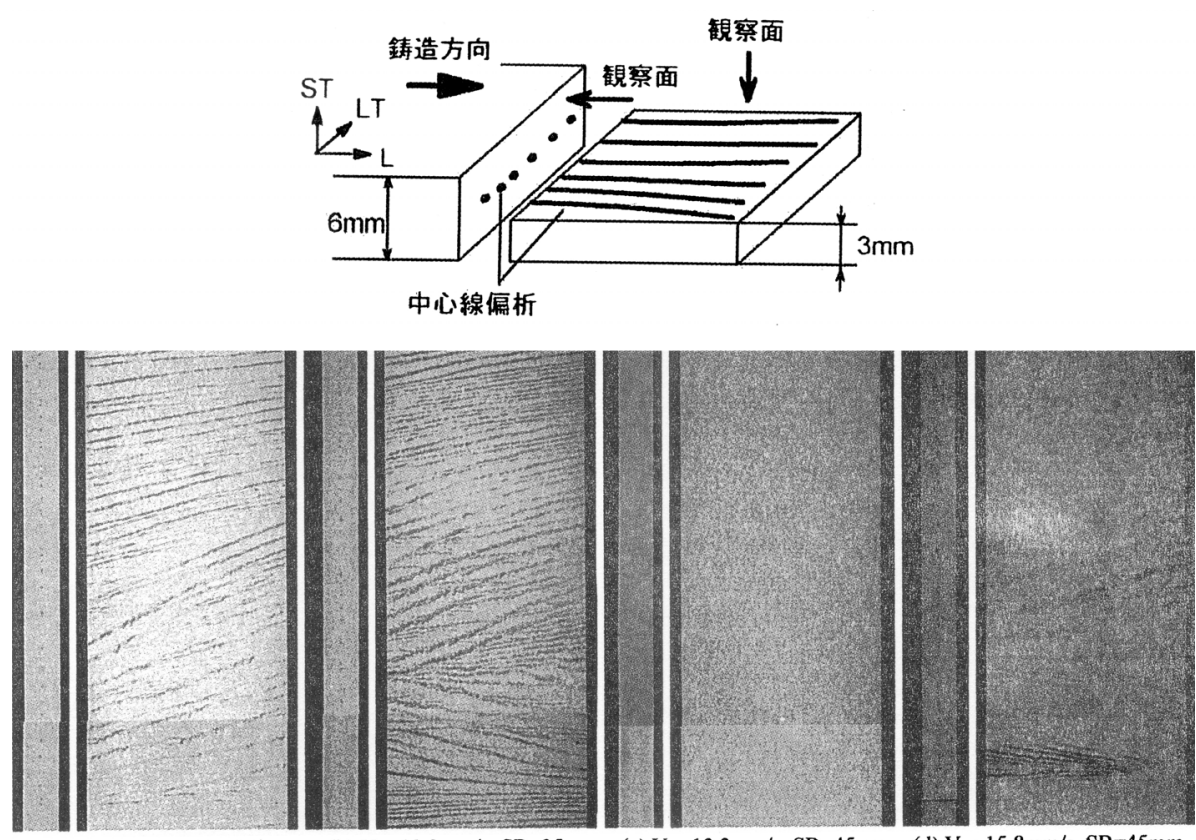

(a) $\mathrm{V}=12.5 \mathrm{~mm} / \mathrm{s}, \mathrm{SB}=35 \mathrm{~mm}$

(b) $\mathrm{V}=13.3 \mathrm{~mm} / \mathrm{s}, \mathrm{SB}=35 \mathrm{~mm}$

(c) $\mathrm{V}=13.3 \mathrm{~mm} / \mathrm{s}, \mathrm{SB}=45 \mathrm{~mm}$

(d) $\mathrm{V}=15.8 \mathrm{~mm} / \mathrm{s}, \mathrm{SB}=45 \mathrm{~mm}$

図 16 チャンネル偏析の模式図とチャンネル偏析に対するロール周速とセットバック長の影響 30),31) $\mathrm{V}$ ：ロール周速, SB：セットバック長, 左：断面, 右：中心部水平面

(a)

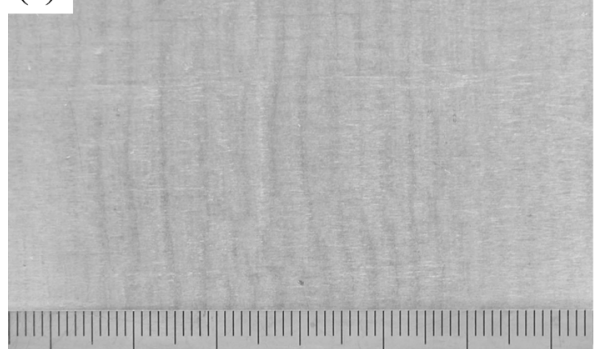

(b)

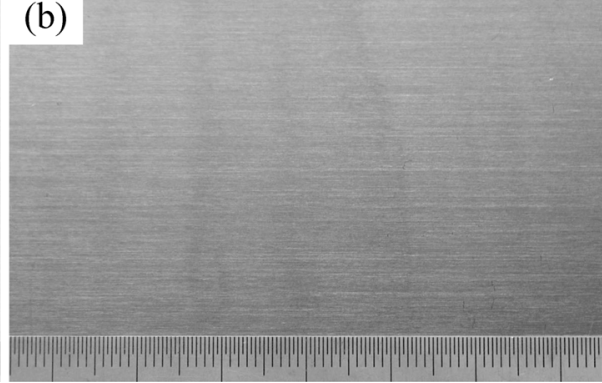

（a）as-cast 板，（b）冷間圧延板
図 17 リップルマークの例 ${ }^{32}$ 
た ${ }^{35)}$ 。ロールキャスト材は冷却速度が高いためマトリックス の共晶 $\mathrm{Si}$ が微細化するので, $\mathrm{SiC}_{\mathrm{p}}$ を添加した複合材でもイン ゴット材と比較すると延性が向上した。

\section{9. 急冷効果による材質の改善}

双ロールキャス夕の急冷効果により材質の改善が期待でき る。ロールキャスト材の引裂勒性は, 真空ダイカスト材之比 較して大きく向上した。ロールキャスト材と真空ダイカスト
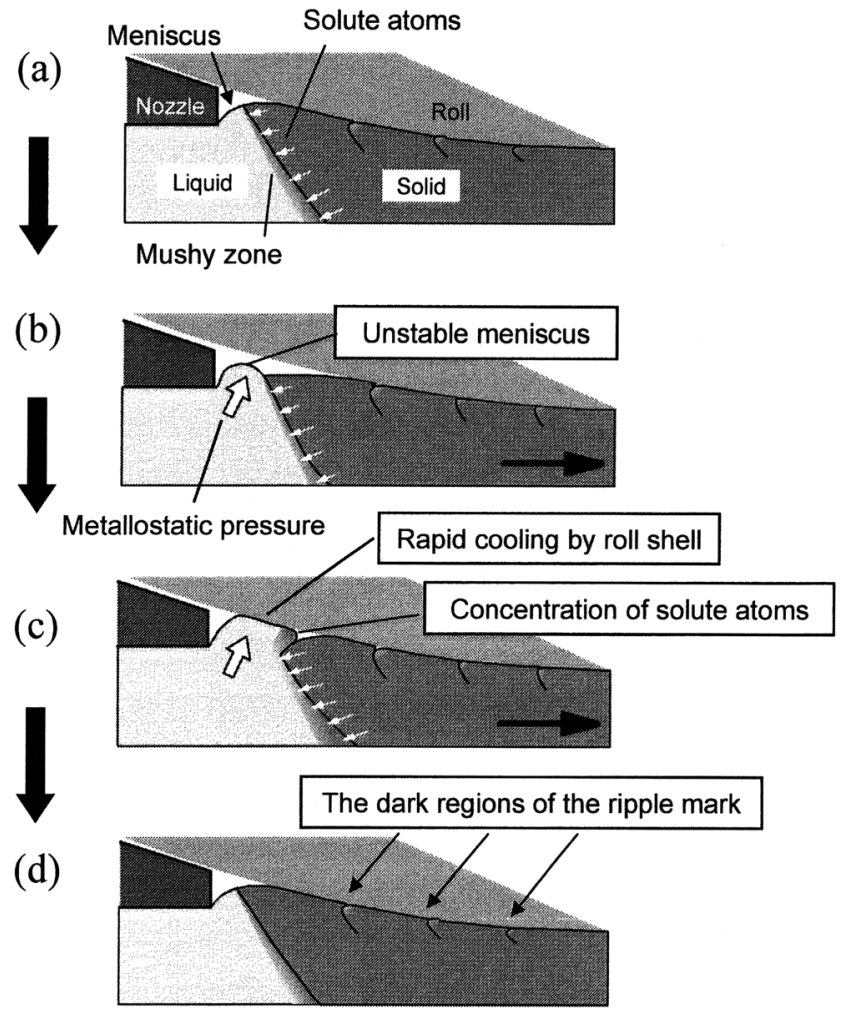

図 18 リップルマークの発生メカニズム ${ }^{32}$

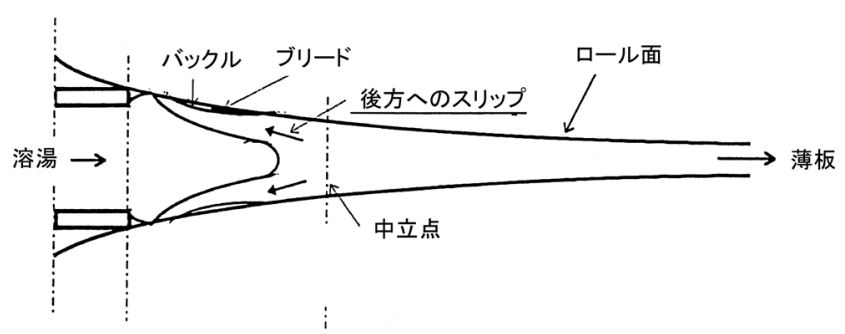

図 19 ブリードの発生メカニズム ${ }^{28), 29)}$
材の単位き裂成長エネルギー $\mathrm{UE}_{\mathrm{p}}$ を比較するとロールキャス ト材では 3 倍に増加した。これは急冷効果により共晶の形態 がラメラ状から球状むしくはロッド状に変化したためとされ ている ${ }^{36)}$ 。

$\mathrm{AC} 4 \mathrm{C}$ は典型的な鋳造用合金であるが, 冷間圧延後 $\mathrm{T} 4$ 処理 した板は，冷間でカップ成形が可能であった。 AC4C 合金の 深絞りカップを図 21 に示す。板の縁のへム加工を行わなけ れば，ロールキャストした $\mathrm{AC} 4 \mathrm{C}$ 合金板むプレス成形に使用 することも可能であると思われる。

自動車のボディシート材などのリサイクルでは, ボルトな どの混入により Fe 量が増し, $\mathrm{Al}-\mathrm{Si}-\mathrm{Fe}$ 系の金属間化合物に よる延性の劣化が予測される。双ロールキャス夕の冷却速度 により Al-Si-Fe 系の金属間化合物を微細化して, 延性, 特に 曲げ性を改善することが試みられている ${ }^{37)}$ 。図 22 に示すよ うにロールキャスト材では急冷効果により $\mathrm{Al}-\mathrm{Si}-\mathrm{Fe}$ 系金属間

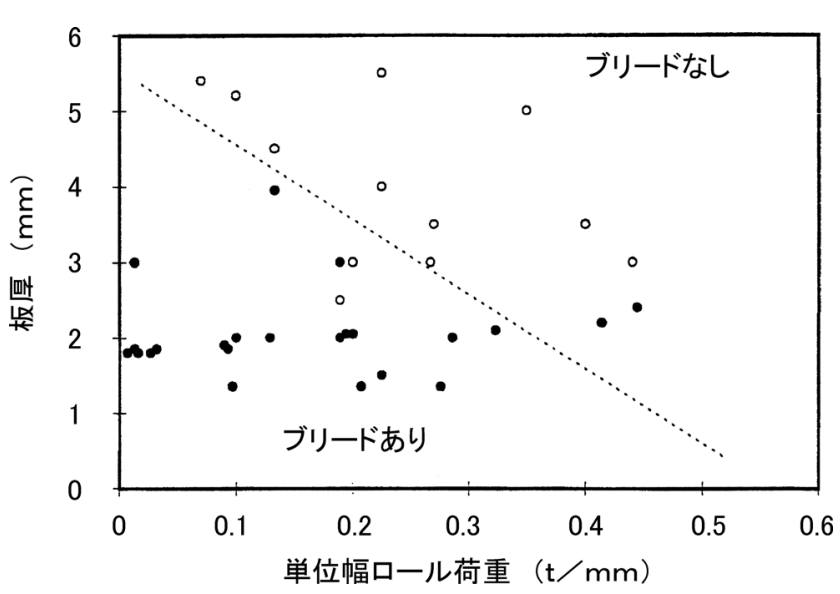

図 20 ブリードの発生に対する荷重と板厚の影響 33$)$

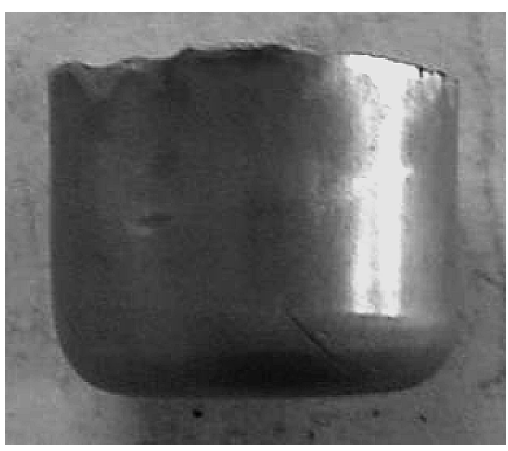

図 $21 \mathrm{AC} 4 \mathrm{C}$ 合金板の深絞り

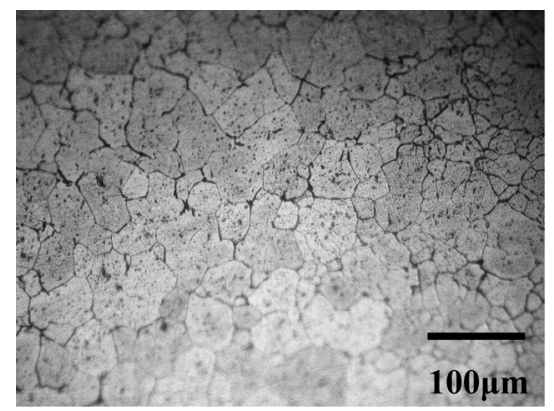

(a) A6063 ロールキャスト板

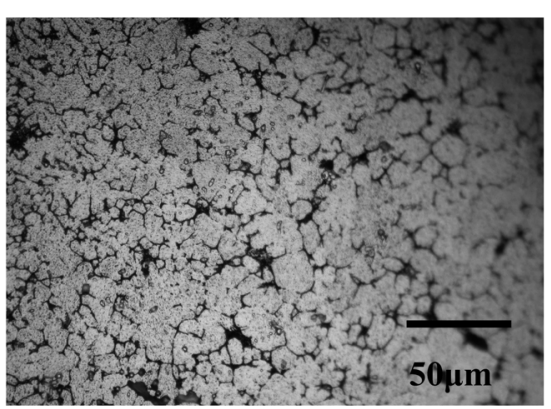

(b) $A 6063+2 \% \mathrm{Fe}$ ロールキャスト板

図 $22 \mathrm{Fe}$ を $2 \%$ 追加した 6063 合金の組織

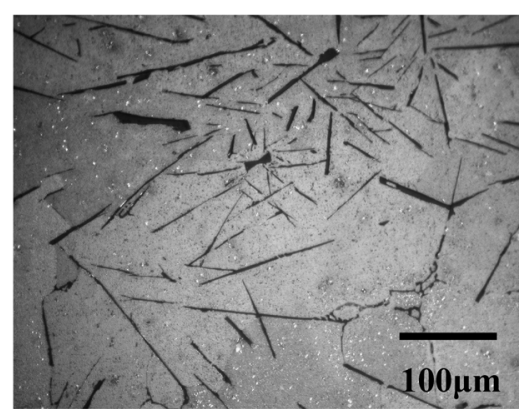

(c) $\mathrm{A} 6063+2 \% \mathrm{Fe}$ 断熱材鋳型 


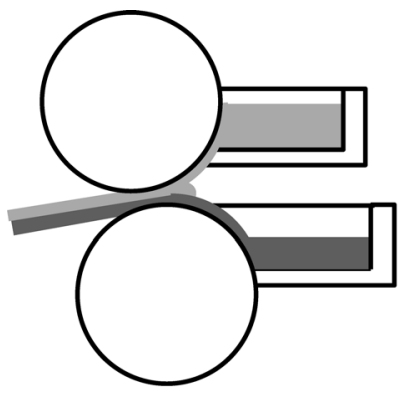

(a)

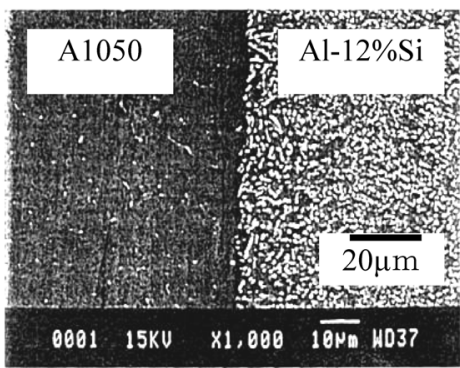

(b)

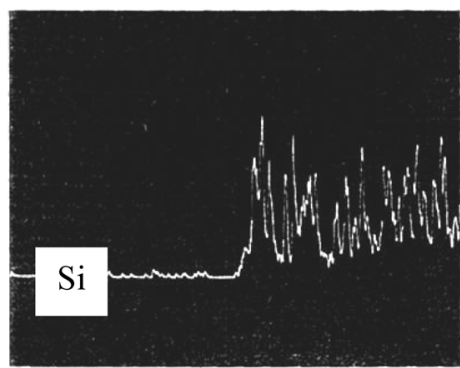

(c)

図 23 双ロールキャスタによるクラッド材の作製 ラッド材断面，（c）接合界面近傍の線分析

（a）クラッド材作製用双ロールキャスタ，（b）接合界面近傍のク

化合物が微細化している。結晶粒径も $100 \mu \mathrm{m}$ 以下であり結 晶粒も微細化している。6016 合金のロールキャスト材は, Fe 量は $0.45 \mathrm{mass} \%$ 程度まで曲げ性は著しく劣化しないようであ る。また，ロールキャストした 6061 合金抢よび $0.2 \mathrm{mass} \% \mathrm{Fe}$ を添加した 6061 合金も 6022 合金と同等の曲げ性を有した ${ }^{38)}$ 。

\section{0. マグネシウム合金}

マグネシウム合金は冷間では変形能が低いため，スラブか ら薄板を作製する場合は熱間圧延を繰返し行う必要がある。 このためマグネシウム合金の薄板は高価である。溶湯から直 接薄板を作製することができれば, 省工程・省エネルギーの 効果はアルミニゥム合金より大きい。1982 年に Hunter はマ グネシゥム合金板の鋳造を行っている ${ }^{2,39), 40) 。 チ ッ フ ゚ に は マ ~}$ グネシウムの溶湯の反応を防ぐため, 特別なコーティングが 施された。AZ31 のような比較的軟質のマグネシウム合金だ けではなく, AZ91のような硬質のマグネシウム合金の板の 鋳造屯行われた ${ }^{2)}$ 。オーストラリアの $\mathrm{CSIRO}^{41)}$, ドイッの $\mathrm{MgF}^{42)}$, 韓国の POSCO, 中国の Yiggung グループ, 日本では 三菱アルミニウム ${ }^{43)}$, 権田金属 ${ }^{44)}$ などがマグネシウムの双 ロールキャスティングの研究や薄板の試作を行っている。権 田金属以外は, 第 1 世代または第 2 世代の双ロールキャス夕 を使用していると思われる。鋳造速度は $5 \mathrm{~m} / \mathrm{min}$ 以下で板厚 は 2 6 $\mathrm{mm}$ である。権田金属は独自の方法で 10 $40 \mathrm{~m} / \mathrm{min}$ の 高速でAZ61 合金板の鋳造に成功している。マグネシウム合 金の双ロールキャスティングにおいても中心線偏析やリップ ルマークはアルミニウム合金と同様に発生する。マグネシウ ム合金は冷間・温間における变形能が低いため, 板表面に割 れが発生しやすい。ロールキャスト板のカップ試験も行われ AM60, AZ61，AZ91 合金のいずれにおいても LDR（限界絞り 比）が 2 以上の実用的な深絞り性が得られた ${ }^{45)}$ 。

\section{1. クラッド材, 複合材}

双ロールキャス夕を用いてクラッド材や長繊維を挿入した 複合材を作製することが試みられている。高荷重で圧下する ことなく 2 層の凝固相を接合することが可能であった。接合 界面近傍の線分析を図 23 に示す。 $\mathrm{Al}-12 \mathrm{mass} \% \mathrm{Si}$ の Si は 1050 一拡散しておらず，接合界面も明膫であった。ロール キャスティングにより針金や金網を内部に挿入した長繊維複 合材を一工程で作製することも可能であった。プロセスと金 網を挿入したロールキャスト板の断面を図 24 に示す。ロー

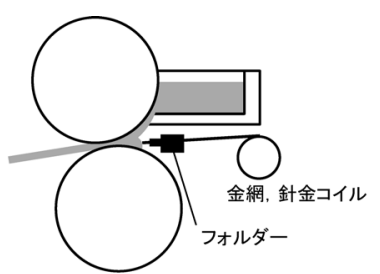

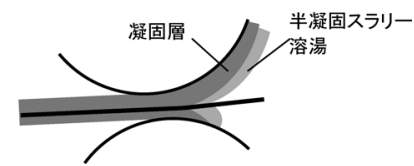

(b)

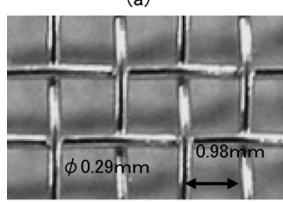

(c)

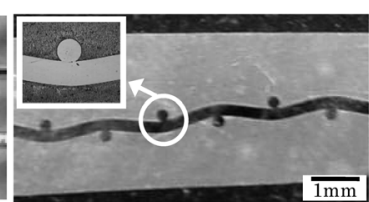

(d)

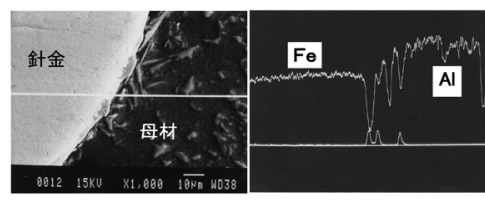

(e)

図 24 金網・針金を挿入したロールキャスト板の作製 （a）金網・針金を挿入した複合材作製用双ロール キャス夕，(b) 挿入部近傍の模式図，(c) 挿入し たステンレス金網，(d) 金網を挿入したロールキャ スト板の断面，(e）挿入した針金近傍の線分析

ルキャスト時に金網を連続的に板の内部へ挿入することが可 能であった。針金が交差する部分においてもマトリックスと 金網の間には隙間は発生しなかった。マトリックスと金網の 組合せ，および鋳造条件が適切であるとマトリックスと金網 は図に示すように反応を起こさなかった。図24で示す方法 で作製した複合材料の板において, 金網の針金が引張方向に 対して 45 度傾いている場合は局部収縮が緩和され, 伸びが 改善された（図 25）。

\section{2. 双ロールキャスタの稼動状況など}

図 262) と図 272) は，薄板作製用プロセスの生産量に対す る設備投資費用およびランニングコストの関係を示す。双 ロールキャスタは, ベルトキャスタまたはブロックキャス夕 之同等, $\mathrm{DC}$ 鋳造と比較すると安価である。新たに工場を建 てるのであれば，図 27 と図 28 より DC 鋳造・熱間圧延から なる薄板の製造設備を導入するより双ロールキャス夕を導入 した方が，メリットが大きいことは明らかである。

図 282) と図 292) は双ロールキャス夕とベルトキャス夕の 


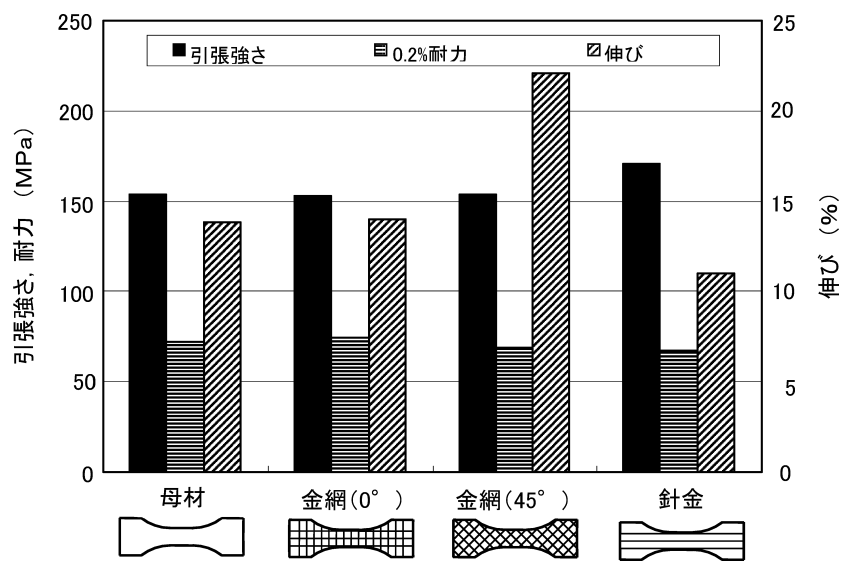

図 25 図 24 の金網を挿入したロールキャスト板の引張試験

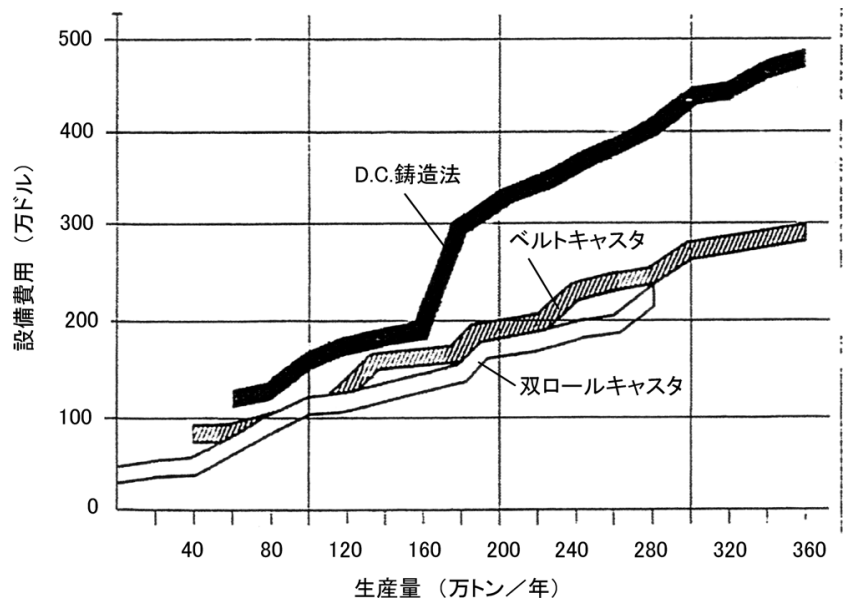

図 26 各生産プロセスの生産量と設備費用の関係 ${ }^{2)}$

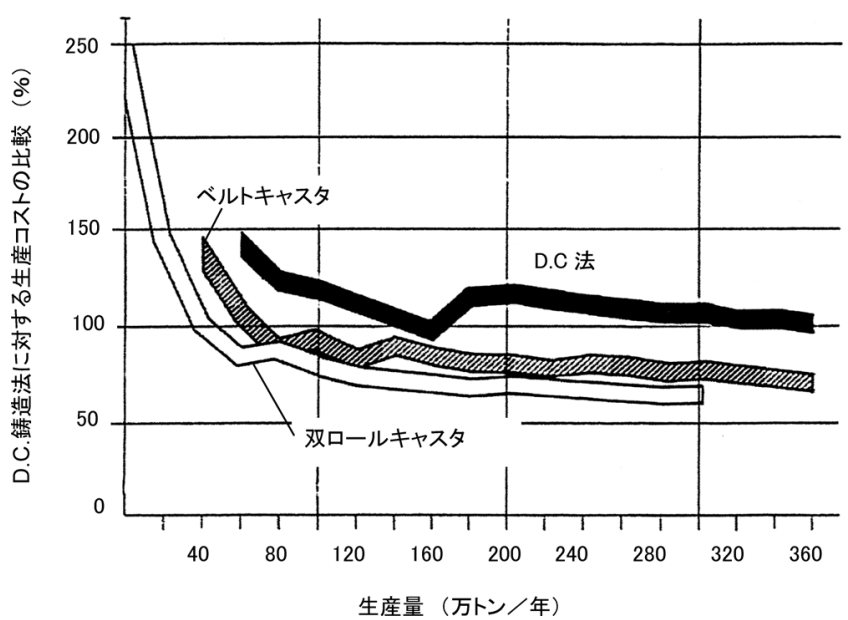

図 27 各生産プロセスの生産量と生産コストの関係 ${ }^{2)}$

稼働台数の推移，およびアルミニウム製品の生産量をキャス タのメーカ別に示している。Hunter製, Pechiney製および中 国製の双ロールキャスタだけで台数执よび生産量ともに全体 の $90 \%$ 以上を占めている。注目すべき点は中国製の双ロー ルキャスタの台数が Pechiney 製より多いことである。図 3046) は中国の双ロールキャス夕による薄板の生産の様子である。 図 312) は地域別の双ロールキャス夕による生産量を示す。中 国に打ける生産量は北米に次ぐ生産量で全世界の $25 \%$ に達

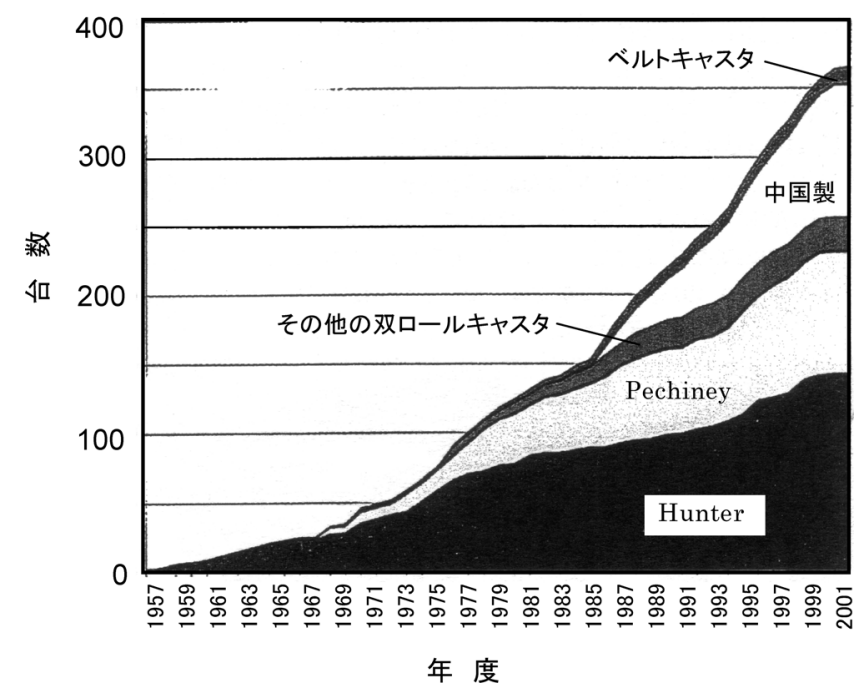

図 28 各種キャス夕台数の推移 ${ }^{2)}$

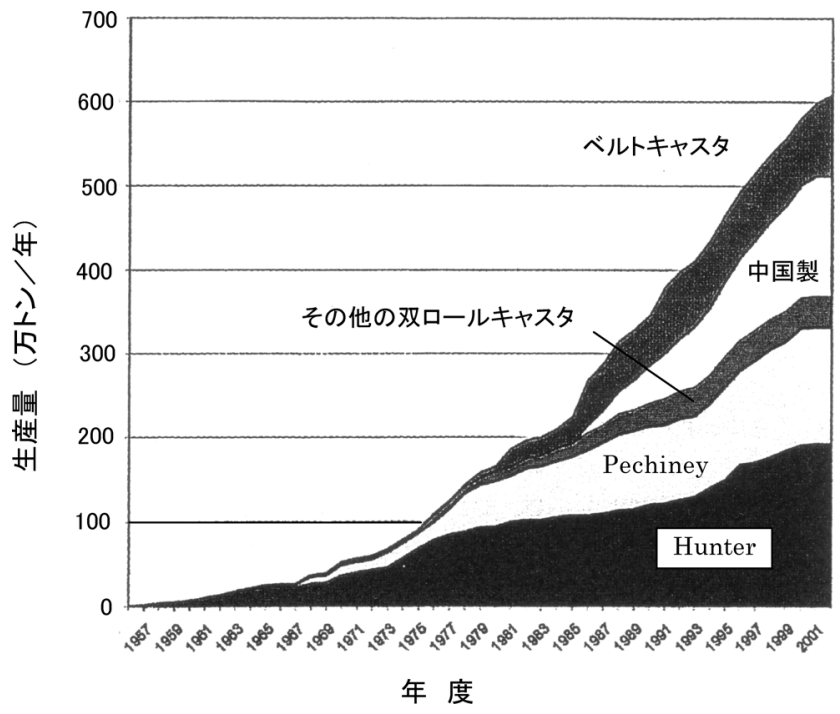

図 29 各種キャス夕の生産量の推移 ${ }^{2)}$

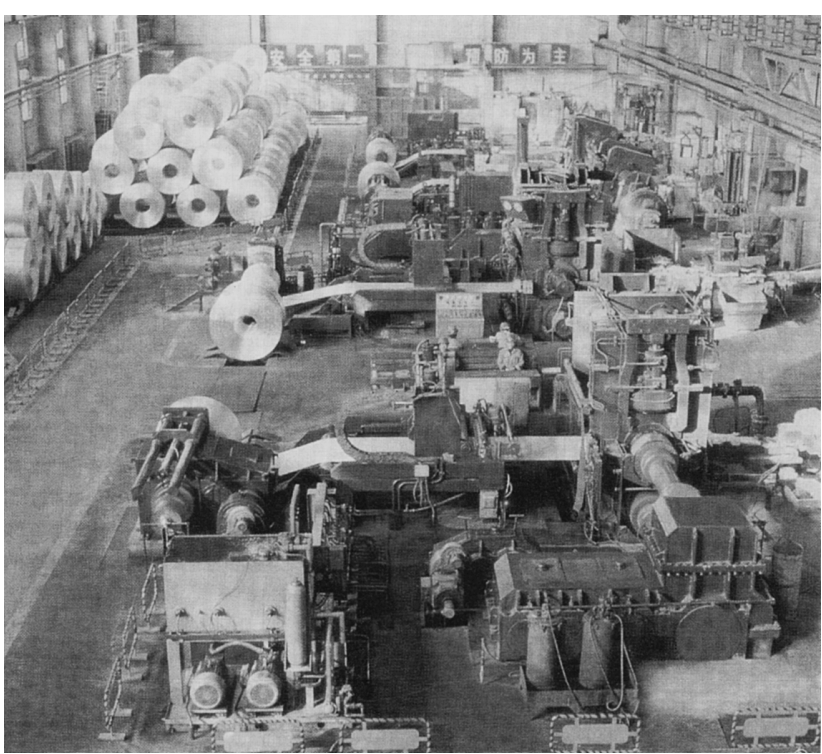

図 30 中国に打ける双ロールキャス夕による生産の様子 ${ }^{46)}$ 


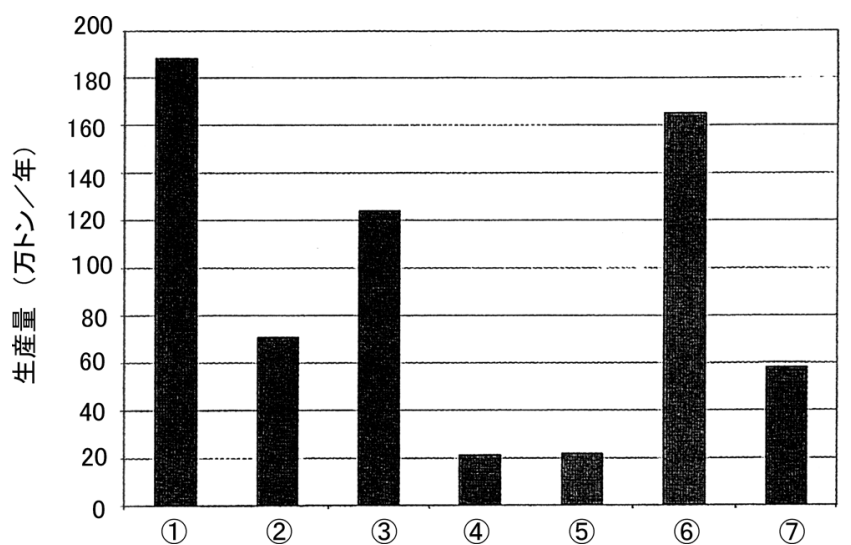

(1)北米, (2)南米, (3) $\mathrm{EU}$ ・ロシア, (4)アフリカ, (5)インド, (6)中国，(7)東南アジア・オーストラリア

図31 地域別双ロールキャス夕による生産量 ${ }^{2)}$

する。中国における双ロールキャス夕の生産台数や稼働台数, 双ロールキャスタによる箔や薄板などの生産量は今後さらに 増加することが予測される。

\section{3.おわりに}

日本はアルミニウム合金用の双ロールキャス夕の導入数は, 欧米やアジアの諸国に比べて格段に少ない。これは, 双ロー ルキャスタが品質と生産性の面で DC 鋳造に劣っているため である。品質の向上と生産性の向上では, 生産性の向上の方 が解決することは容易であると思われる。熱間圧延による鍛 錬効果と同等の効果を熱処理と圧下率の低い冷間圧延で得る ことは，非常に困難であると思われる。DC 鋳造と同じ合金 種で同等の品質の製品を双ロールキャスタで鋳造することを 目指すことが，双ロールキャス夕の目標設定として妥当であ るか，また，それが不可能な場合に双ロールキャス夕を否定 するかは慎重に検討する必要がある。

双ロールキャス夕の使用目的は単に低コスト化だけではな い。リサイクル材に含まれる不純物の無害化や難加工材の薄 板の作製など双ロールキャス夕の特徽, 特に急冷効果と薄板 を溶湯から直接鋳造することができる省工程の利点を生かし た使用方法を模索すべきであると考えられる。

\section{参 考 文 献}

1）例えば，塩沢正一・草川隆次・松浦佑次：塑性と加工， 2-11 (1961), 801-808.

2) S. Hamer, C. Romanowski and B. Taradlio: Light Met. Age, Vol. 60, 9-10 (2002), 6-17.

3）三木 功，小菅張弓，長浜勝介：軽金属，25（1975），1

4) Alum. Int. Today, Vol. 14 (2002), 39-40.

5) B. Traglio and C. Romanowski: Light Met. 1995 (1995), 1165-1182.

6) A. I. Nussbaum: Light Met. Age, 55 (1997), 34-38.

7) Alum. Int. Today, Vol. 13 (2001), 26-28.

8) R. Beals, B. Carey, B. Taraglio and C. Romanowski: Alum. Cast Technol., (1997), 351-362.

9) B. Carey, R. Beals and C. Romanowski: Melt Spin Strip Cast Slab Cast,
(1995), 29-41.

10) M. Duendar, O. Keles and B. Dogan: Light Met. 2004 (2004), 723-737.

11) S. Hamer, D. Smith, C. Romanowski, G. Yildizbayrak and B. Taraglio: Light Met. 1999 (1999), 931-937.

12) S. Etran, M. Dundar, Y. Birol, K. Sariogular, E. Ozden, S. Akkurt, G. Yildizbayrak, S. Hamer and C. Romanowski: Light Met. 2000 (2000), 667-672.

13) M. Cortes: Light Met. 1995 (1995), 1161-1164.

14) A. I. Nussbaum: Light Met. Age, 55 (1997), 34-39.

15） P. Y. Menet, R. Cayol and J. Moriceau: Light Met. 1997 (1997), 753756.

16) M. Cortes: Alum. Cast House Technol., (1995), 379-386.

17) P. M. Thomas, P. G. Grocock and J. M. Bouzendorffer: Metal Plant Technol. Int, 20 (1997), 44-52.

18) Alum. Today, 19 (1997), 13.

19) M. Duendar, A. S. Akkurt and K. Sarioglu: Light Met. 2003 (2003), 719-724.

20) J. M. Chateau and P. H. Solignac: Light Met. 1989 (1989), 667-672.

21) B. Frischknecht and K. P. Miwald: Light Met. 1988 (1988), 365-372.

22） Bruno Prezezzis 社のカタログより

23) J. Canon and D. Smith: Light Met. 2000 (2000), 629-633.

24) K. Sarioglu, G. Yildizbayrak and M. Dundar: Light Met., Vol. 2000 (2000), 663-666.

25) http://www.fatahunter.com/_new_08/continuous_casting_optiflow_ casthousel.htm

26) D. Smith, O. Keles and N. Dogan: Light Met. 2004 (2004), 719-722.

27) O. Daaland, A. B. Espedal, M. L. Nedreberg and I. Alvestad: Light Met. 1997 (1997), 745-752.

28) S. A. Lockyer, M. Yun and J. D. Hunt: Mater. Charact., 37 (1996), 301-310.

29) M. Yun, S. A. Lockyer and J. D. Hunt: Mater. Sci. Eng., 70 (2000), 550-558.

30）江崎宏樹, 渡辺良夫, 箕田 正, 宇都秀之, 渋江和久：軽金属 学会第 107 回秋期大会講演概要, (2004), 37.

31）江崎宏樹, 箕田 正, 上田 薰, 渡辺良夫 : 軽金属学会第 108 回春期大会講演概要，(2005), 57.

32）江崎宏樹, 渡辺良夫, 上田 薰, 宇都秀之, 渋江和久：軽金属, 56 (2006), 266.

33) M. Yun, J. D. Hunt and S. A. Lockyer: Int. J. Met. Res., 13 (2001), 255-261.

34) P. Griffiths, D. V. Edomonds and J. D. Hunt: Process Prop. Appl. Met. Ceram. Mater., 1 (1992), 207-212.

35) P. A. Karnezis, G. Durant, B. Cantor, E. J. Palmiere: Mater. Sci. Technol., 11 (1995), 741-751.

36）熊井真次, 小林 慶, 朱 洪, 鈴木健太, 羽賀俊雄：軽金属, 55 (2005), 500-506.

37）阪口 洋, 羽賀俊雄, 乾 秀喜, 熊井真次, 渡利久規: 鋳造工 学, 79 (2007), 523-528.

38）乾 秀喜, 羽賀俊雄, 阪口 洋, 熊井真次, 渡利久規 : 鋳造工 学, 79 (2007), 537-544

39) R. E. Brown: Light Met. Age, 60 (2002), 80-83.

40) Light Met. Age, 60 (2002), 101.

41) Mater. World, 11 (2003), 29-30.

42) E. Bernhard: Light Met. Age., 63 (2005), 14-19.

43) Y. Nakaura, A. Watanabe and K. Ohori: Mater. Trans. JST, 47 (2006), 1743-1749.

44）権田源太郎, 権田善夫, 津崎二三雄 : アルトピア, 35 (2005), 9-15.

45）古閑伸裕, ラッチャニーパイサーン, 石原直剛, 渡利久規, 羽 賀俊雄：軽金属, 57 (2007), 141-145.

46）ある，420（2002），18-24. 